\title{
The impact of cryopreservation with polyvinyl alcohol on the survival and functional activity of rat testis interstitial cells
}

\author{
O. V. Pakhomov ${ }^{1,2,3}$, O. S. Sidorenko ${ }^{1,4}$ \\ ${ }^{1}$ Institute for Problems of Cryobiology and Cryomedicine, NAS of Ukraine \\ 23, Pereyaslavskaya Str., Kharkiv, Ukraine, 61015 \\ 2 V. N. Karazin Kharkiv National University \\ 4, Svobody Ave., Kharkiv, Ukraine, 61022 \\ ${ }^{3}$ Kharkiv National Medical University \\ 4, Nauki Ave., Kharkiv, Ukraine, 61022 \\ ${ }^{4}$ Institute for Scintillation Materials, NAS of Ukraine \\ 60, Lenin Ave., Kharkiv, Ukraine, 61001 \\ aleksandr.pakhomov2017@gmail.com
}

\begin{abstract}
Aim. To investigate the impact of polyvinyl alcohol (PVA) in cryoprotective media on the survival and proliferation of rat testis interstitial cells (ICs) after cryopreservation. Methods. Rat ICs were obtained by enzymatic processing of testis with collagenase (type I) and DNase I. The obtained cells were cryopreserved by three methods. Methods 1 and 2 implied the use of cryoprotective medium (CM) based on $1.4 \mathrm{M}$ dimethylsulfoxide (DMSO) and $10 \%$ fetal cow serum (FCS) but utilized different cooling rates to $-70{ }^{\circ} \mathrm{C}$. Method 1 : ICs were cooled with $1{ }^{\circ} \mathrm{C} / \mathrm{min}$. Method 2: after initiation of crystallization the cells were cooled with $15^{\circ} \mathrm{C} / \mathrm{min}$ to $-40^{\circ} \mathrm{C}$ and with $20^{\circ} \mathrm{C} /$ min from -40 to $-70{ }^{\circ} \mathrm{C}$. Method 3 implied the cooling rate of $1{ }^{\circ} \mathrm{C} / \mathrm{min}$ but FCS was replaced by $20 \mathrm{mg} / \mathrm{ml}$ PVA. When the temperature $-70^{\circ} \mathrm{C}$ was reached the samples were plunged into liquid nitrogen $\left(-196^{\circ} \mathrm{C}\right)$. After warming and removal of CM the ICs were cultured in Ham's/F12 with and without human chorionic gonadotropin (hCG). Results. The use of method 2 improved the survival of Leydig cells in samples to $79.5(70.0 ; 90.0) \%$ comparing with method 1 (42.0 $(37.0 ; 47.0) \%)$. The use of PVA in method 3 did not have an effect on ICs and Leydig cell survival comparing with method 1 . Cell culturing showed that the number of Leydig cells in wells rose to $17(0.09 ; 0.39)$ and $0.12(0.08 ; 0.14) \times 10^{6}$ after cryopreservation by methods 2 and 3 , respectively, when the cells were stimulated with hCG. These values are several times higher than the initial number of cells in the wells $\left(0.65(0.57 ; 0.71) \times 10^{4}\right)$. Conclusion. PVA in combination with other components of cryoprotective medium promoted the survival of Leydig cells capable of further proliferation in culture, especially, in the presence of hCG.
\end{abstract}

Keywo rd s: testis interstitial cells, Leydig cells, cryopreservation, polyvinyl alcohol, cell proliferation, human chorionic gonadotropin.

(C) 2021 O. V. Pakhomov et al.; Published by the Institute of Molecular Biology and Genetics, NAS of Ukraine on behalf of Biopolymers and Cell. This is an Open Access article distributed under the terms of the Creative Commons Attribution License (http://creativecommons.org/licenses/by/4.0/), which permits unrestricted reuse, distribution, and reproduction in any medium, provided the original work is properly cited 


\section{Introduction}

Testis interstitial cells (ICs) are the biological material that can be used for preservation of endangered species, breeding farm and laboratory animals $[1,2]$. They are critical for the mammal reproductive function because of their production of sex hormones. All these make ICs very important material for transplantation $[3,4]$.

Practical use of ICs requires their adequate reserve. Thus the development and modernization of long-term storage of ICs are of great interest. Traditionally, the cryoprotective media containing dimethylsulfoxide (DMSO), a penetrating cryoprotective agent, in concentration of $0.7-2.1 \mathrm{M}$ and the blood serum or serum albumin, which is a natural biopolymer of the serum, are utilized for cryopreservation of ICs $[5,6]$. The cited researches also use the cooling rate $1{ }^{\circ} \mathrm{C} / \mathrm{min}$. We have worked out and described an alternative method for cryopreservation of ICs that promotes the survival of Leydig cells in IC suspension [7-9]. These two methods are common in a way they both use DMSO and blood serum but they differ in the cooling rate in the bulk ice mass melting and the eutectic melting ranges of cryopreservation media that promotes higher survival of Leydig cells in samples.

The use of blood serum under cryopreservation of cells imposes significant restriction for their further practical application. It is well known that blood serum may contain pathogenic microorganisms, which cause zoonotic diseases, or prions, leading to neurodegenerative processes. Sterilization of donor serum proteins does not guarantee the elimination of all pathogens [10-12]. The use of autologous serum or serum albumin in cryopreservation media does not address the challenge because it often involves preoperative manipulations, additional funds and cannot be fulfilled under certain circumstances. The utilization of blood serum containing media makes impossible unification of these media for cryopreservation and cultivation of cells and results in inconsistency of the medium composition from batch to batch [13] One of the perspective way out of the problem is the use of various high molecular weight polymers instead of blood serum or serum albumin in cryoprotective media $[14,15]$. The synthetic polymer polyvinyl alcohol (PVA) can inhibit recrystallization during cooling or heating [16]. It can also adsorb on the surface of growing crystals thus inhibiting the rate of their growth that in turn increase the survival rate of biological material after cryopreservation [17]. Therefore, the objective of the research is to investigate the impact of PVA in cryoprotective media on the survival and proliferation of rat testes ICs after cryopreservation.

\section{Materials and Methods}

The experimental protocol was in accordance with the Guide for Care and Use of Laboratory Animals, which was approved by the Committee for Bioethics in Animal Experimentation of the Institute for Problems of Cryobiology and Cryomedicine NAS of Ukraine and is a subject to the European Convention for the Protection of Vertebrate Animals used for Experimental and Other Scientific Purposes.

The ICs isolation was carried out as outlined below: the donors, 5-6-month[-old] 
adult male Wistar rats, were sacrificed by cervical dislocation and immersed in $70 \%$ ethanol (Vishpha, Ukraine) for $5 \mathrm{~min}$. The testes were decapsulated, trimmed of blood vessels and placed in 15-ml centrifuge tubes with $4 \mathrm{ml}$ of DMEM (PAA, Austria) per testis with $0.2 \mathrm{mg} / \mathrm{ml}$ collagenase (type I) (SigmaAldrich, USA) and $0.1 \mathrm{mg} / \mathrm{ml}$ DNase I (Sigma-Aldrich) for $10 \mathrm{~min}$ in a thermostated shaking water bath $\left(90\right.$ cycles $/ \mathrm{min}$ at $\left.34^{\circ} \mathrm{C}\right)$. $10 \mathrm{ml}$ of collagenase-free DMEM were added to each tube and the seminiferous tubule mass was removed by filtration through doubled $100-\mu \mathrm{m}$ nylon mesh. The filtrates were centrifuged at $325 \mathrm{~g}$ for $3 \mathrm{~min}$ at room temperature. The supernatants were discarded. The residues were re-suspended in $10 \mathrm{ml}$ of DMEM and supplemented with $100 \mathrm{IU} / \mathrm{ml}$ penicillin (Arterium Corporation, Ukraine) and $100 \mu \mathrm{g} / \mathrm{ml}$ streptomycin (Arterium Corporation). The procedure of sedimentation was repeated.

Two types of cryoprotective media (CM) were used:

- CM-1 contained 1.4 M DMSO, $10 \%$ fetal cow serum (FCS) (Biowest, France) in Ham's/F12.

- CM-2 contained 1.4 M DMSO, $20 \mathrm{mg} / \mathrm{ml}$ PVA (M.m. 9 kDa) in Ham's/F12.

The exposition time of ICs in the CM came to $15 \mathrm{~min}$. The cooling of the samples was done in cryocontainers (Nunc, Denmark) with programmable freezer (developed in the Institute for problems of cryobiology and cryomedicine, Kharkiv, Ukraine). Three methods of cryoconservation were used:

Method 1 included the cooling to $-70{ }^{\circ} \mathrm{C}$ at the rate $1{ }^{\circ} \mathrm{C} / \mathrm{min}$. When the temperature was reached the samples were plunged into liquid nitrogen $\left(-196{ }^{\circ} \mathrm{C}\right) . \mathrm{CM}-1$ was used. The cooling rate for cryopreservation of Leydig cells was proposed by Tai and Chen $[5,6]$. The method was considered as a control for the comparisons with methods 2 and 3.

Method 2 included the cooling to $-0{ }^{\circ} \mathrm{C}$ at the rate of $1{ }^{\circ} \mathrm{C} / \mathrm{min}$. After that the procedure of crystallization initiation (seeding) was provided by the programmable freezer. Then the samples were cooled with $15{ }^{\circ} \mathrm{C} / \mathrm{min}$ to $-40{ }^{\circ} \mathrm{C}$ (this is the range where the bulk ice mass is formed) and with $20{ }^{\circ} \mathrm{C} / \mathrm{min}$ from -40 to $-70{ }^{\circ} \mathrm{C}$. The last range encompassed the eutectic point of DMSO solutions $\left(-67.6^{\circ} \mathrm{C}\right)$. When the temperature $-70{ }^{\circ} \mathrm{C}$ was reached the samples were plunged into liquid nitrogen $\left(-196{ }^{\circ} \mathrm{C}\right)$. The method was developed in the Institute for problems of cryobiology and cryomedicine, NAS of Ukraine, and used CM-1 [7-9]. The method was compared with method 3.

Method 3 included cooling to $-70{ }^{\circ} \mathrm{C}$ at the rate $1{ }^{\circ} \mathrm{C} / \mathrm{min}$. When the temperature was reached the samples were plunged into liquid nitrogen $\left(-196^{\circ} \mathrm{C}\right)$. CM-2 was used.

The samples were warmed in a water bath at $37{ }^{\circ} \mathrm{C}$ till the crystal phase disappeared. $\mathrm{CMs}$ and their components were removed by gradual dilution of the samples with Ham's/ F12 medium. Then the cell suspension was centrifuged and supernatant was discarded. After this ICs were resuspended in Ham's/F12 medum. The procedure of CM removal was repeated again. Finally, the ICs volume was adjusted to $1 \mathrm{ml}$ with Ham's/F12.

The amount of cells before and after cryopreservation was calculated in Goryaev chamber. General cell survival was calculated using the formula: 


$$
\mathrm{Sg}=(\mathrm{C} 1 / \mathrm{C} 2) \times 100 \%,
$$

where $\mathrm{C}_{1}$ was the total amount of cells after cryopreservation and $\mathrm{C}_{2}$ was the amount of cells before cryopreservation.

Cell viability was assessed by means of trypan blue dye (TBD) (Sigma-Aldrich, USA) exclusion, which was added to the cell suspension in a 1:1 ratio to reach the end concentration of $2 \mathrm{mg} / \mathrm{ml}$. Viability was calculated using the formula:

$$
\mathrm{V}=(\mathrm{C} 1 / \mathrm{C} 2) \times 100 \% \text {, }
$$

where $\mathrm{C}_{1}$ was the amount of cells that were not stained with TBD in a sample and $\mathrm{C}_{2}$ was the total amount of cells in this sample.

Histochemical staining for $3 \beta$-hydroxysteroid dehydrogenase ( $3 \beta$-HSD) was carried out using the method described in [18]. This enzyme is one of the key enzymes in steroid hormone biosynthesis in Leydig cells. $50 \mu \mathrm{l}$ of cell suspension were dried on a microscope glass slide for at least 1 hour at room temperature. The cells were covered with staining solution prepared by mixing two solutions $\mathrm{A}$ and $\mathrm{B}$. Solution A contained $1 \mathrm{mg}$ of nitro blue tetrazolium and $0.6 \mathrm{mg}$ of dehydroepiandrosterone in $0.6 \mathrm{ml}$ of DMSO. Solution B contained 10 $\mathrm{mg}$ of $\beta-\mathrm{NAD}^{+}$in $10 \mathrm{ml}$ of phosphate buffer solution (PBS). Cells were stained for 2 hours, rinsed in distilled water, and fixed in $10 \%$ formalin in PBS with $5 \%$ sucrose. A coverslip was mounted with glycerol:PBS (1:1) solution. ICs were observed at $600 \times$ magnification for the presence of blue-purple formazan. The cells were counted in the microscopic field of view.

Survival of Leydig cells after cryopreservation was calculated using formula:

$$
\mathrm{SL}=(\mathrm{C} 1 / \mathrm{C} 2) \times 100 \%
$$

where $\mathrm{C}_{1}$ was the amount of positively stained cells $\left(3 \beta-\mathrm{HSD}^{+}\right)$after cryopreservation and $\mathrm{C}_{2}$ was the amount of $3 \beta-\mathrm{HSD}^{+}$before cryopreservation.

To determine the ability of ICs to proliferation and differentiation, the native and cryopreserved cells were cultivated for 14 days in 24 well plates (SPL Life Sciences, Korea) in the Ham's/F12 solution with $10 \%$ FCS. $8.7 \times 10^{4}$ cells in $1 \mathrm{ml}$ were placed on each well. Half of these cell samples were cultivated with human chorionic gonadotropin (hCG) (Schering-Plough Central East, Switzerland) for the steroidogenesis stimulation. To determine the amount of Leydig cells in the cultivated samples, the reagents for $3 \beta$-HSD staining were brought in the wells after removal of cultivating medium and drying.

Data are represented as median, 25th/75th percentiles, and minimal/maximal values. The Kruskal-Wallis test was used to find the differences between the groups. Additionally, the data were ranked and Newman-Keuls test was used for multiple comparisons of groups using Statistica 6.0 (Tulsa, OK, USA).

\section{Results and Discussions}

Cryopreservation of ICs showed, that the cooling rate significantly influenced general survival of cells and the survival of Leydig cells (fig. 1, A). The use of method 2 that was worked out to improve the Leydig cell yield after cryopreservation [7-9] increases their survival to $79.5(70.0 ; 90.0) \%$. This value is approximately two times higher comparing with method $1(42.0(37.0 ; 47.0) \%)$.

Conversely, the change of $10 \%$ serum (method 1$)$ for $2 \%$ PVA (method 3 ) did not 

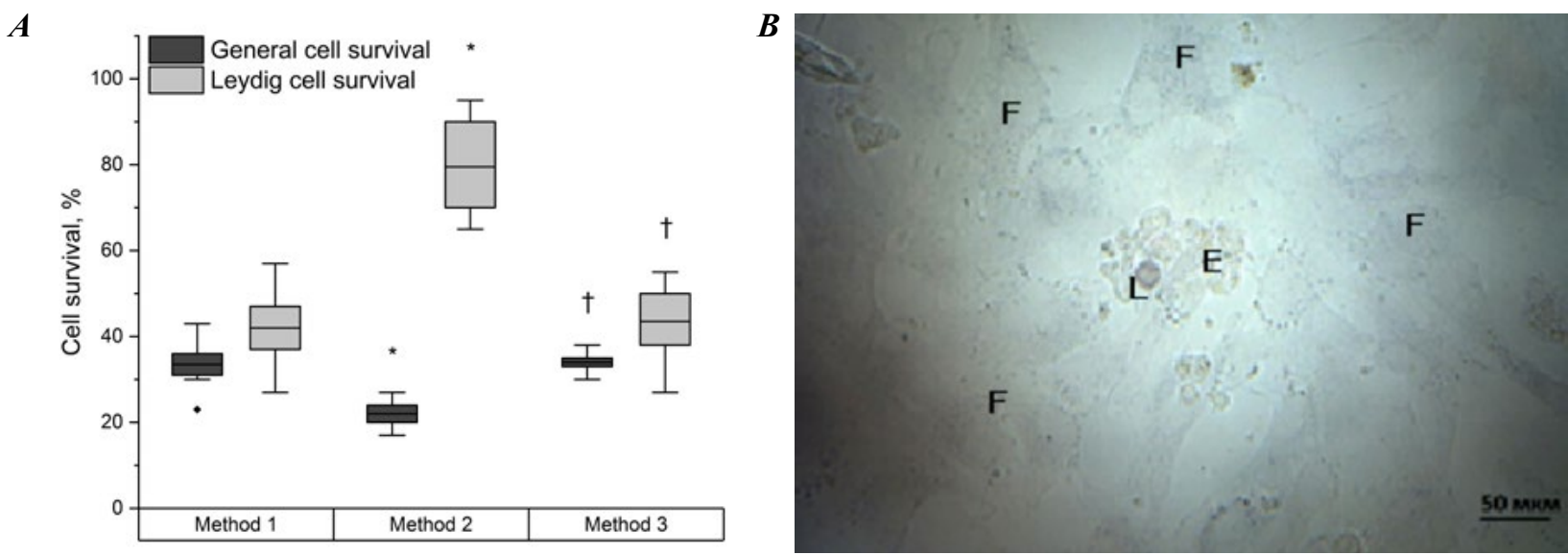

Fig. 1. General cell survival and survival of Leydig cells after crypreservation (A). Histochemical staining for $3 \beta$-HSD in ICs culture (B): $E$ - epithelioid cells, $F$ - fibroblast like cells, $L-3 \beta-\mathrm{HSD}^{+}$cell.

$* \mathrm{p} \leq 0.05$, the difference is statistically significant with respect to method 1 ;

$\dagger \mathrm{p} \leq 0.05$, the difference is statistically significant with respect to method 2 .

have any effect on general cell survival and Leydig cell survival. The viability of ICs came to $94.0(90.0 ; 98.0) ; 80(75.0 ; 85.0)$ and 89.5 $(85.0 ; 93.0) \%$ for methods 1,2 and 3 , respectively. Thus, the general survival as well as viability of ICs cryopreserved by method 3 were higher than those for method 2.

Proliferation of ICs in culture was assessed at the next stage. Generally, it was shown two morphological types of cells in culture: the fibroblast cells that were linked to one another by the processes forming two-dimensional network; the single or grouped epithelioid cells that were localized between fibroblast cells. Some of these cells were $3 \beta-\mathrm{HSD}^{+}$ (Fig. 2, B).

It is well known that one of the indicators of functional activity of cells is their ability to proliferation and differentiation in culture. We evaluated the number of native and cryopreserved cells on days 7 and 14 of cultivation. We also assessed the number of Leydig cells in culture with and without hCG.
It was shown that the proliferative activity of cryopreserved samples increased (Fig. 2, A and $\mathrm{B}$ ) but the effect of cryopreservation on the Leydig cells proliferation and differentiation was less pronounced (Fig. 2, C and D). ICs cryopreserved by methods 1 and 2 had the highest proliferative activity. However, noteworthy, ICs cryopreserved by method 2 and 3 had a higher ability to produce Leydig cells in culture when comparing with method 1. Additionally, hCG stimulated proliferation and differentiation of the Leydig cell precursors into the mature Leydig cells in culture but did not have any effect on ICs culture on the whole. The number of Leydig cells in a well rose to $17(0.09 ; 0.39)$ and $0.12(0.08 ; 0.14)$ $\times 10^{6}$ after cryopreservation by method 2 and 3 , respectively, when the cells were stimulated with hCG. These values are several times higher than the initial number of cells in a well $\left(0.65(0.57 ; 0.71) \times 10^{4}\right)$.

Low-temperature storage of biological objects and their damage during the process of 
$A$

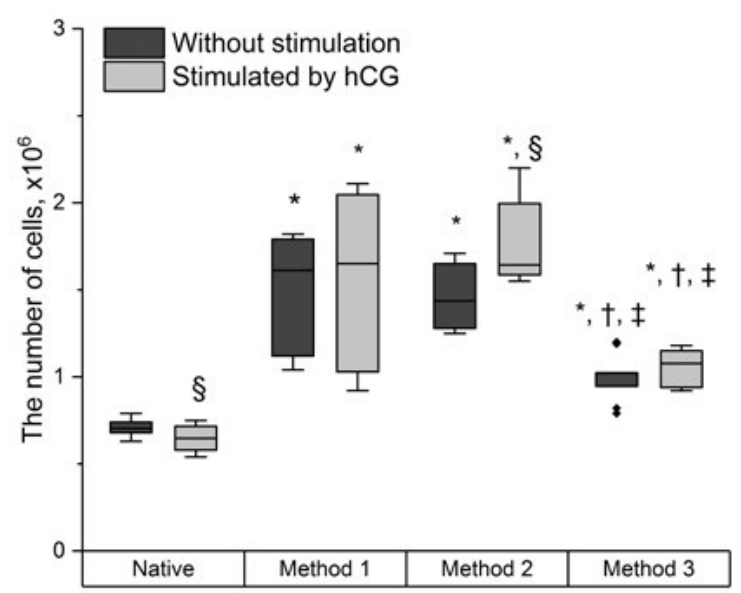

$C$

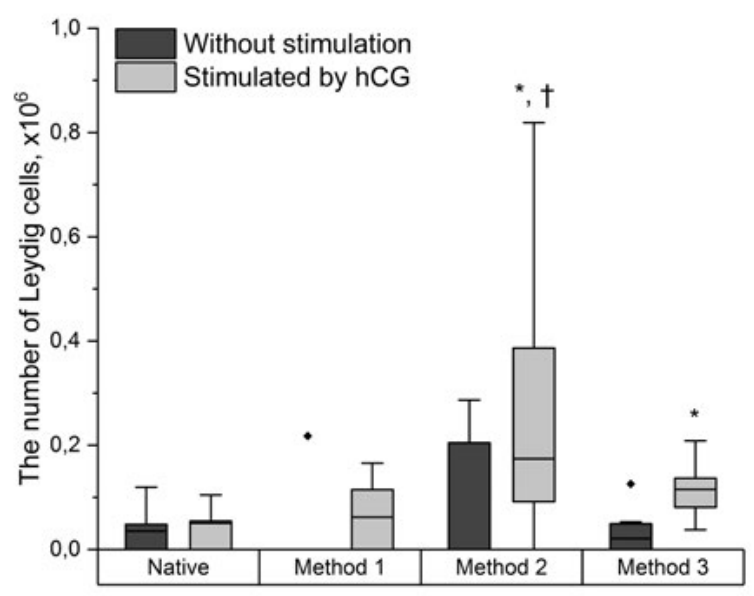

B

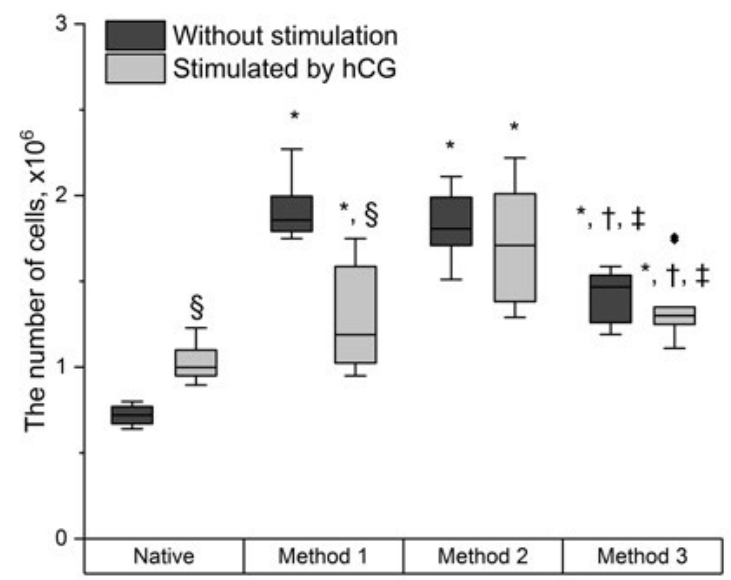

D

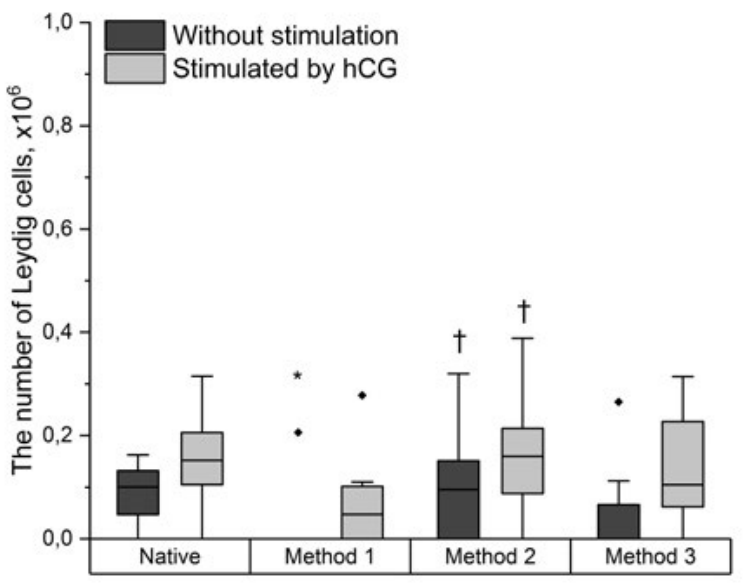

Fig. 2. Total amount of ICs in a well by days 7 (A) and 14 (B) of cultivation. The number of Leydig cells in a well by days 7 (C) and 14 (D) of cultivation.

$* \mathrm{p} \leq 0.05$, the difference is statistically significant with respect to native;

$\dagger \mathrm{p} \leq 0.05$, the difference is statistically significant with respect to method 1 ;

$\pm \mathrm{p} \leq 0.05$, the difference is statistically significant with respect to method 2 ;

$\S p \leq 0.05$, the difference is statistically significant with respect to the culture without stimulation.

cryopreservation are directly linked with the changes in the state of matter and with phase transitions occurring in cells, tissues and surrounding extracellular liquid. Low cooling rates can result in the formation of extracellular ice, the growth of which triggers an increase in osmolarity of extracellular liquid, water loss by cells, a reduction in cell volume and membrane damage [19]. High cooling rates lead to the intracellular ice formation that may damage cellular structure. The use of cryoprotective agents such as DMSO decreases the water loss by the cells and crystal growth during cryopreservation thus eliminating the 
cryodamage described above and promoting the cell survival. The cryoprotective properties of blood serum is mainly linked with albumin, which may inhibit the crystal growth [20,21]. Such agents also stabilize cellular membranes, prevent osmotic lesion of cells, protect cells from free radical [22], however their use is restricted because of the reasons mentioned in the introduction.

Therefore, to improve the yield of ICs after cryopreservation it is necessary to optimize cooling rates in various temperature ranges or to modify the composition of cryoprotective media. The first approach was realized in method 2 and was described by us earlier [7-9]. The second one was shown in method 3 where the composition of cryoprotective media was modified: the blood serum was replaced by $2 \%$ PVA. Taking into account cryoprotective properties of PVA and DMSO the following conclusion can be drawn: on the one hand, the combined action of PVA and DMSO prevented the critical crystal formation; on the other hand, the absorption of extracellular water by PVA increased viscosity, facilitated moderate dehydration of ICs, prevented the excessive water loss and promoted cell survival.

hCG is a stimulator of testosterone synthesis by Leydig cells and an activator of their proliferative activity [23]. Some works have shown its immunosuppressive effect [24] manifested in the inhibition of the proliferation of immune competent cells widely spread throughout testis interstitium [25]. This can explain the absence of hCG action on ICs in the culture in general and its stimulating action with respect to Leydig cells and their precursors in the culture.

\section{Conclusions}

The results of the research have shown that the use of PVA allows the preservation of considerable amount of ICs that can be used in further study. PVA in combination with other components of cryoprotective medium promoted the survival of Leydig cells capable of further proliferation in culture, especially, in the presence of hCG. This is evidenced by high amount of the cells by days 7 and 14 of cultivation comparing to the samples cryopreserved by method 1 that utilized identical cooling rate of $1{ }^{\circ} \mathrm{C} / \mathrm{min}$ but differed in the composition of media. High preservation of Leydig cells cryopreserved by method 2 points to the possibility of the modernization of cryopreservation process not only at the expense of medium composition but also by means of the cooling rate variation in different temperature ranges. This can be used for the further development of the methods of low-temperature storage of testicular cells and other objects.

\section{REFERENCES}

1. Schlatt S, Honaramooz A, Boiani M, Schöler HR, Dobrinski I. Progeny from sperm obtained after ectopic grafting of neonatal mouse testes. Biol Reprod. 2003;68(6):2331-5.

2. Woelders H, Windig J, Hiemstra SJ. How developments in cryobiology, reproductive technologies and conservation genomics could shape gene banking strategies for (farm) animals. Reprod Domest Anim. 2012;47 Suppl 4:264-73.

3. Kirpatovskii VI, Efremov GD, Frolova EV, Kudryavtseva $L V$. Stimulation of Spermatogenesis and Synthesis of Testosterone by Allotransplantation of Neonatal Testicular Tissue under Tunica Albuginea of Cryptorchid Testis. Bull Exp Biol Med. 2019; 166(4):497-502. 
4. Gao X, Chang XB, Wu RY, Zhan BY. Allotransplantation of cryopreserved human Leydig cells. Transplant Proc. 1994;26(6):3490.

5. Tai J, Tze WJ, Johnson $H W$. Cryopreservation of rat Leydig cells for in vitro and in vivo studies. Horm Metab Res. 1994;26(3):145-7.

6. Chen GR, Ge RS, Lin H, Dong L, Sottas CM, Hardy MP. Development of a cryopreservation protocol for Leydig cells. Hum Reprod. 2007;22(8):2160-8.

7. Hurina TM, Pakhomov OV, Bozhok HA, Bondarenko TP. Method for cryopreservation of testicular cell suspen-sion of mammals. Patent UA, no. 91787, 2010.

8. Gurina TM, Pakhomov AV, Bozhok GA. Effect of Cooling Rate under Various Temperature Intervals on Survival of Steroidogenic Potential of Suspension of Interstitial Cells of Adult Rat's Testes. Problems of Cryobiology and Cryomedicine. 2007; 17(4): 394-402.

9. Gurina TM, Pakhomov AV, Kyryliuk AL, Bozhok GA. Development of a cryopreservation protocol for testicular interstitial cells with the account of temperature intervals for controlled cooling below $-60^{\circ}$ C. Cryobiology. 2011;62(2):107-14.

10. Truyen U, Parrish CR, Harder TC, Kaaden OR. There is nothing permanent except change. The emergence of new virus diseases. Vet Microbiol. 1995;43(2-3):103-22.

11. Hinckley GT, Johnson CJ, Jacobson KH, Bartholomay C, McMahon KD, McKenzie D, Aiken JM, Pedersen JA. Persistence of pathogenic prion protein during simulated wastewater treatment processes. Environ Sci Technol. 2008;42(14):5254-9.

12. van Os HC, Drogendijk AC, Fetter WP, Heijtink RA, Zeilmaker GH. The influence of contamination of culture medium with hepatitis B virus on the outcome of in vitro fertilization pregnancies. $\mathrm{Am} \mathrm{J}$ Obstet Gynecol. 1991;165(1):152-9.

13. Snyman E, Van der Merwe JV. Endotoxin-polluted medium in a human in vitro fertilization program. Fertil Steril. 1986;46(2):273-6.

14. Petrenko YuA. Cryopreservation of human embryonic liver cells using DMSO and high molecular weight polymers. Problems of Cryobiology. 2003; (3): 80-7.
15. Liu Y, Xu X, Ma XH, Liu J, Cui ZF. Effect of various freezing solutions on cryopreservation of mesenchymal stem cells from different animal species. Cryo Letters. 2011;32(5):425-35.

16. Knight $C A$, Wen $D$, Laursen $R A$. Nonequilibrium antifreeze peptides and the recrystallization of ice. Cryobiology. 1995;32(1):23-34.

17. Tekin K, Daşkın A. Effect of polyvinyl alcohol on survival and function of angora buck spermatozoa following cryopreservation. Cryobiology. 2019; 89:60-67.

18. Klinefelter GR, Hall PF, Ewing LL. Effect of luteinizing hormone deprivation in situ on steroidogenesis of rat Leydig cells purified by a multistep procedure. Biol Reprod. 1987;36(3):769-83.

19. Pegg DE. Principles of cryopreservation. Methods Mol Biol. 2015;1257:3-19.

20. Zakharov B, Fisyuk A, Fitch A, Watier Y, Kostyuchenko A, Varshney D, Sztucki M, Boldyreva E, Shalaev E. Ice Recrystallization in a Solution of a Cryoprotector and Its Inhibition by a Protein: Synchrotron X-Ray Diffraction Study. J Pharm Sci. 2016; 105(7):2129-38.

21. Bruyère P, Baudot A, Joly T, Commin L, Pillet E, Guérin P, Louis G, Josson-Schramme A, Buff S. A chemically defined medium for rabbit embryo cryopreservation. PLoS One. 2013;8(8):e71547.

22. Liu Y, Xu X, Ma X, Martin-Rendon E, Watt S, Cui Z. Cryopreservation of human bone marrow-derived mesenchymal stem cells with reduced dimethylsulfoxide and well-defined freezing solutions. Biotechnol Prog. 2010;26(6):1635-43.

23. Riccetti L, De Pascali F, Gilioli L, Potì F, Giva LB, Marino M, Tagliavini S, Trenti T, Fanelli F, Mezzullo M, Pagotto U, Simoni M, Casarini L. Human LH and hCG stimulate differently the early signalling pathways but result in equal testosterone synthesis in mouse Leydig cells in vitro. Reprod Biol Endocrinol. 2017;15(1):2.

24. Nisula B, Bartocci A. Choriogonadotropin and immunity: a reevaluation. Ann Endocrinol (Paris). 1984;45(4-5):315-9.

25. Zhao S, Zhu W, Xue S, Han D. Testicular defense systems: immune privilege and innate immunity. Cell Mol Immunol. 2014;11(5):428-37. 
Вплив кріоконсервування 3 полівініловим спиртом на збереженість і функціональну активність інтерстиціальних клітин сім'яників щурів

\section{О. В. Пахомов, О. С. Сидоренко}

Мета. Вивчити вплив полівінілового спирту (ПВС) в кріозахисному середовищі на виживання і проліферацію інтерстиціальних клітин (ІК) сім'яників щурів після кріоконсервування. Методи. ІК отримували 3 сім'яників щурів ферментативним методом з використанням колагенази (тип I) і ДНКази І. Отримані клітини кріоконсервували за трьома методами. У методах 1 і 2 використовувалося кріозахисне середовище (КС) на основі 1,4 М диметилсульфоксиду (ДМСО) і $10 \%$ фетальної телячої сироватки (ФТС), при цьому застосовувалися різні швидкості охолодження до $-70{ }^{\circ} \mathrm{C}$. Метод 1: ІК охолоджували зі швидкістю $1{ }^{\circ} \mathrm{C} / \mathrm{xв.}$ Метод 2: після початку кристалізації клітини охолоджували зі швидкістю $15^{\circ} \mathrm{C} /$ хв до $-40{ }^{\circ} \mathrm{C}$ і зі швидкістю $20^{\circ} \mathrm{C} /$ хв від -40 до $-70{ }^{\circ} \mathrm{C}$. Метод 3 передбачав швидкість охолодження $1{ }^{\circ} \mathrm{C} / \mathrm{xв}$, але ФТС була замінена на 20 мг/мл ПВС. При досягненні температури $-70{ }^{\circ} \mathrm{C}$ зразки занурювали в рідкий азот $\left(-196{ }^{\circ} \mathrm{C}\right)$. Після нагрівання і видалення кріозахисного середовища ІК культивували в середовищі Наm's/F12 з хоріонічним гонадотропіном людини (ХГЛ) і без нього. Результати. Використання методу 2 дозволило підвищити виживаність клітин Лейдіга в зразках до 79,5 $(70,0 ; 90,0) \%$ в порівнянні з методом 1 (42,0 (37,0; $47,0) \%$ ). Використання ПВС в методі 3 не вплинуло на виживання IК і клітин Лейдіга в порівнянні з методом 1. Культивування клітин показало, що кількість клітин Лейдіга в лунках збільшилася до $17(0,09 ; 0,39)$ і $0,12(0,08 ; 0,14) \times 10^{6}$ після кріоконсервування за способами 2 і 3 відповідно, коли клітини стимулювали ХГЛ. Ці значення в кілька разів перевищують вихідну кількість клітин в лунках $\left(0,65(0,57 ; 0,71) \times 10^{4}\right)$. Висновок. ПВС в поєднанні з іншими компонентами кріозахисного середовища сприяв збереженню клітин Лейдіга, здатних до подальшої проліферації в культуpi, особливо в присутності ХГЛ.

Кл ю ч о в і с л о в а: інтерстиціальні клітини сім'яників, клітини Лейдіга, кріоконсервування, полівініловий спирт, проліферація клітин, хоріонічний гонадотропін людини.

\section{Влияние криоконсервирования с поливиниловым спиртом на сохранность и функциональную активность интерстициальных клеток семенников крыс}

А. В. Пахомов, О. С. Сидоренко

Цель. Изучить влияние поливинилового спирта (ПВС) в криозащитных средах на выживаемость и пролиферацию интерстициальных клеток (ИК) семенников крыс после криоконсервирования. Методы. ИК получали из семенников крыс ферментативным методом с использованием коллагеназы (тип I) и ДНКазы І. Полученные клетки криоконсервировали тремя методами. В методах 1 и 2 использовалась криозащитная среда (КС) на основе 1,4 М диметилсульфоксида (ДМСО) и $10 \%$ фетальной телячьей сыворотки (ФТС), при этом применялись различные скорости охлаждения до $-70{ }^{\circ} \mathrm{C}$. Метод 1 : ИК охлаждали со скоростью $1{ }^{\circ} \mathrm{C} /$ мин. Метод 2: после начала кристаллизации клетки охлаждали со скоростью $15^{\circ} \mathrm{C} /$ мин до $-40{ }^{\circ} \mathrm{C}$ и со скоростью $20^{\circ} \mathrm{C} /$ мин от -40 до $-70{ }^{\circ} \mathrm{C}$. Метод 3 предполагал скорость охлаждения 1 ${ }^{\circ} \mathrm{C} /$ мин, но ФТС была заменена на 20 мг/мл ПВС. При достижении температуры $-70{ }^{\circ} \mathrm{C}$ образцы погружали в жидкий азот $\left(-196{ }^{\circ} \mathrm{C}\right)$. После нагревания и удаления криозащитной среды ИК культивировали в среде Наm's/ F12 с хорионическим гонадотропином человека (ХГЧ) и без него. Результаты. Использование метода 2 позволило повысить выживаемость клеток Лейдига в образцах до 79,5 $(70,0 ; 90,0) \%$ по сравнению с методом $1(42,0$ $(37,0 ; 47,0) \%)$. Использование ПВС в методе 3 не повлияло на выживаемость ИК и клеток Лейдига по сравнению с методом 1. Культивирование клеток показало, что количество клеток Лейдига в лунках увеличилось до 17 $(0,09 ; 0,39)$ и $0,12(0,08 ; 0,14) \times 10^{6}$ после криоконсервирования способами 2 и 3 соответственно, когда клетки стимулировали ХГЧ. Эти значения в несколько раз превышают исходное количество клеток в лунках $(0,65(0,57$; $\left.0,71) \times 10^{4}\right)$. Вывод. ПВС в сочетании с другими компонентами криозащитной среды способствовал сохранению клеток Лейдига, способных к дальнейшей пролиферации в культуре, особенно в присутствии ХГЧ.

К л юч е в ы е с л о в а: интерстициальные клетки семенников, клетки Лейдига, криоконсервирование, поливиниловый спирт, пролиферация клеток, хорионический гонадотропин человека.

Received 27.09.2020 